\title{
A Framework For Principals: Promoting Student Success Through Leadership And Collaboration
}

Max E. Fridell, (E-mail: mfridel@mail.nwmissouri.edu), Northwest Missouri State University Kris Alexander, (E-mail: kalex@mail.nwmissouri.edu), Northwest Missouri State University

\begin{abstract}
What's a principal to do? How can a principal stay on top of the demands of the job and be successful? How can the principal construct strategies that will invite solidarity, cooperation, and shared decision-making, and yet, at the same time, focus on student achievement? This article provides a framework in which key concepts are addressed, all geared to reckon with the demands of the principal as instructional leader. To meet these challenges, educational leaders need to address a clear vision for change, an engaging learning environment, a collegial commitment for improvement, the importance of multicultural education, and the inclusion of technology.
\end{abstract}

\section{INTRODUCTION}

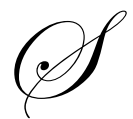

chools in the United States continue to evolve into complex and culturally diverse institutions. Because of the added stress created by the need to meet acceptable standardized test score platforms and due to the increasing demands to show accountabilities, principals at all levels could increase their odds of success by conceptualizing and implementing an educational framework by which they form and implement decisions. In order to help students get the most out of their education, it is crucial that school leaders provide and influence environments that are couched in a variety of sound educational practices. In continuing efforts to create rewarding learning opportunities, principals must keep clear their goals in the midst of the daily rigor and the occasional debacle.

When a school encounters situations that may be unique to its established norms, it is important that the environment supports a clarity of vision for change, a strong focus on the learning environment, a collegial commitment for continual improvement, an acceptance and understanding of diversity, and an appreciation for the benefits of technology for the purposes of promoting and underscoring education. Imbued throughout is the necessary autonomy for teachers that allows for creativity and innovation within the framework of curriculum standards.

Providing principals with the necessary knowledge that will better enable them to serve the school system is a complex goal undertaken, in part, by higher education instructors whose job it is to instruct current and future educational leaders. The purpose here is two-fold: to engage both prospective and practicing principals in recognizing and managing productive learning environments; and, through the principal's leadership, to involve the community in collaboration toward the same projected outcomes. Inherent in the process of attaining a teaching certificate, of taking hours toward a post-bachelor's degree, or of reflecting and adjusting teaching and administrative styles, the aim is one of allowing these higher education students multiple opportunities to develop leadership skills that will aid them in structuring positive school climates and in influencing best practice strategies for the benefit of their faculties and students, both current and future.

\section{ESTABLISHING A VISION}

Educational leadership, regardless of whether it is involves the management of a learning environment or the collaboration with families and community members, involves establishing and sharing a clear vision for progress. A vision is a shared concept, one that provides appropriately challenging parameters to everyone involved with the 
school, including parents and students. Vision allows for direction by putting in front of those involved a "goaloriented mental construct that guides people's behavior" (Seeley, 1992, Vision, \ 1). Especially for principals, a vision provides a clearly defined, thoughtfully produced picture of the future that establishes pathways and serves to guide the school forward.

Not only does a clearly developed vision serve to propel the school forward, but it also allows for success as it keeps programs from becoming waylaid, as it maintains educator morale and motivation, and as it remains focused on the processes of improvement. As a solid point of reference, a school's vision serves as the foundation for communication whereby educators are able to judge their progress, stay connected with each other, and become empowered to make productive changes in classroom practices. With empowerment comes leadership responsibility. Here, the most important role of the educational leader is to "communicate, protect and defend the commitment statements, and address behavior that is incongruent with the statements" (Eaker, DuFour, \& DuFour, 2002, p. 132).

Because vision focuses on change, it should not be regarded as permanently fixed. As the school and community cultures change, so too should the vision. The over-zealous administrator who realizes the importance of a vision but fails to take into account the culture, the perceived needs of the school by those representing the culture, or the need of teachers to feel empowered will soon reach failure and frustration. Collaboration with an eye toward shared values tempered with concern for and understanding of others will result in team ownership and, as a result, more positive results (Stolp, 1994). Zmuda, Kuklis, \& Kline refer to "collective autonomy" and describe it as a collaboration "in pursuit of shared goals and interests that serve the individual and the system" (2004, p. 61). "Collective autonomy," the authors continue, "is a hallmark of a competent system" (p. 61-62) and one whose legitimacy is "based on how well it represents all perspectives in the school community" (p. 18).

A vision cooperatively developed with and communicated to all concerned (students, educators, parents, and patrons) provides a strong motivation because the vision is based on shared values. Mathews (1996) pinpoints vision as a means of engaging patrons, who seem, overall, to becoming increasingly disconnected, to the aims and charges of the school. A vision must be "felt in the heart and addressed every day" (Connors, 2000, p. 65). Vision, then, becomes "a hunger to see improvement" (Pejza, 1985, no page number).

Knowing the definitions of vision and the reasons of its importance are not enough. How does a principal go about creating a vision? Bringing the superintendent on board and keeping in line with the district-wide mission statements, the principal should examine not only his/her own hopes for the progress of the school, but those of the faculty, staff, students, and community as well. One such method involves surveying, constructing community discussion groups, and establishing a broad-base of support.

In creating survey instruments, it is well-advised to keep in mind several potential driving forces: values; budget (both current and projected); technology; the role of local, state, and federal governments; educational trends; building limitations; the availability of additional resources; and information dissemination and collection. The latter is important in maintaining strong contact with those individuals who have sincere interest in this vision building process. Surveys to determine satisfaction may be a place to start. Several commercial survey instruments exist (many put together by university professors) or the principal may customize the instrument in order to determine the satisfaction of students, faculty, and community.

Make it known from the beginning that all parties vested in interest are encouraged to participate. Engage citizens in brainstorming groups, not only to provide ideas for survey items, but also to interpret the results and brainstorm for future action. Have the broad-base community group develop a pro/con or advantage/disadvantage list for each component as the process unfolds. Follow this up with printed reports for dissemination and continued consensus-building discussion meetings. As the principal undertakes this venture, it is wise to remember that feedback becomes an immediate goal, and, as such, communication should be geared for ease and useful function. All communication going out should be readable, written in plain language, succinct, positive, and engaging. Keeping one eye on the present and the other to the future is the key to a well-organized vision developing process. 


\section{MANAGING THE LEARNING ENVIRONMENT}

Just like the yin yang symbol forms two parts of the whole, apparent in the hidden curriculum are student achievement and school climate working in harmony in order to generate a positive working environment or a negative one. "Low teacher morale usually leads to indifference toward others; cynical attitudes toward students; little initiative when it comes to preparing lessons and other classroom activities; preoccupation with leaving teaching for a better job; increased use of sick leave; and bouts of depression. Discouraged teachers are a drain on a school system, but more important, teachers with unhealthy attitudes often are a symptom of an unhealthy school organization." (Black, 2001). Principals have direct influence over teachers' perception of their job satisfaction and morale.

Basic to the concept of the principal's ability to manage the learning environment is her/his ability to handle problems, value attitudes, promote an environment where all are treated with respect, and create conditions that motivate others to be positive and strive for success. It is important that principals understand their responsibilities in reckoning with obstacles, either by removing them, creating stiles to step over them, or forging new paths to walk around them.

The learning environment of a school and the schools' culture are each inherent in the other's definition. Deal and Peterson (1993) defined school culture simply as "inner reality" (p. 89). Others, including Robbins and Alvy (1995), have tied it to the expectations of administrators, teachers, and students. Phillips and Wagner's (2003) definition characterizes the learning culture as a collection of "beliefs, attitudes, and behaviors" (p. 4) that are reflected in people's treatment of each other, feelings of inclusion and appreciation, and rituals "reflecting collaboration and collegiality" (p. 3). Banks' definition focuses more on the communication of this social system to the students in that the learning environment of the school "communicates to the students the school's attitudes toward a range of issues and problems, including how the school views them as human beings..." (Banks, 1993, p. 24). Wren's (1993) writings examine school culture from the hidden curriculum perspective and offers an eight-point guide to assist educators in examining symbols found in the school for the purpose of recognizing and improving the school's learning environment. Regardless of the definition, open communication, high expectations, involvement in decision-making, tangible support through visible leadership, and trust are common components in competently designed and led school systems.

Charlotte Danielson's book entitled Four Domains of Teaching Responsibility (1996) offers a discussion of the practicality of a positive classroom environment. Danielson's classroom environment domain is comprised of five components: "Creating an Environment of Respect and Rapport," "Establishing a Culture for Learning," "Managing Classroom Procedures," "Managing Student Behavior," and "Organizing Physical Space." A common bond found throughout these components is a respectful classroom environment that "cultivates a culture for learning and creates a safe place for risk-taking" (p. 31). In analyzing Danielson's frameworks, it is when students are involved in making decisions that the level of performance rises to the distinguished level.

In establishing a classroom learning environment that promotes decision making among students, and in keeping with the engaging yet professional atmosphere of the academic setting, it is important to prepare students to be collaborators - or, one whose opinions are valued and respected. Tinzmann, et al. (1990) echoed Danielson's work in recognizing the importance of student involvement in the creation of collaborative classrooms -- classrooms where students' roles depend upon purposeful decision-making, active participation and strong communication. As principals focus on the management of the overall learning environment, it would be smart to keep in mind the impact of the classroom environment on the overall school learning climate, and, thus, the importance of students within this mix.

Proactive planning is important in determining how much impact student behavior management will play in the flow of the daily routine and, hence, what positive or negative influences it will have on the school climate. Positive learning conditions are essential to a well-run school; a negative or apathetic environment is a fault in the very foundation of the school's purpose. Productive learning environments occur because of careful attention to student achievement and favorable student attitudes, and such environments are derived "from careful thought and planning" (Kellough \& Kellough, 2003, p. 71). To be clear, it is the responsibility of administrators and teachers alike 
to generate a fair and equitable behavior management plan that speaks to maintaining a productive learning environment.

Among the principal's tasks is the responsibility to not only develop and manage an overall positive and productive school climate, but to keep abreast of the various individual classroom climates that exist within the building. This knowledge will provide a more comprehensive view of the entire school climate and offer important information for the management of the learning environment.

Approximately thirty years ago, the emphasis in classroom management switched to that of teacher as reactionary to that of teacher as preventionist. Kounin's 1970 study set the stage for modern teacher classroom management programs with his concepts of "withitness," (p.80) and "overlapping" (p. 85). Pacing, (Edwards, 2004), consistent monitoring of students' behavior (Weinstein, 2003), and Kounin's "ripple effect" (Kellough \& Kellough, p. $77,2003)$ are all components of early preventionist strategies. Much of the negative side of behavior management, it was determined, could be alleviated with proactive planning that addressed preventative measures and controlled the small problems as soon as possible in order to prevent them from rising to greater magnitude.

Canter established a formalized, teacher-centered approach with his assertive discipline strategy that rewarded compliance and punished disruptions (Canter, 1976). Assertive discipline, to some, became too stringent, and the results from a series of studies concluded that "in spite of teacher and administrator perceptions that are often positive, there is not evidence that Assertive Discipline training results in improved student behavior" (Emmer and Aussiker, 1989, p. 119).

Soon after, several other classroom management strategies surfaced. Jones' (1987) Positive Classroom Discipline system focused on interactive teaching, teacher delivery (particularly effective body language), setting limitations, and time management. Glasser followed with his emphasis on student satisfaction, classroom meetings, quality curriculum, non-coercive teaching styles (1990), and, later, highlighting student choice (1998).

The flood gates opened and in rushed a number of classroom management strategies, each with their own key to success: Coloroso's (1994) inner-discipline, Fay and Funk's (1995) love and logic, Albert's (1996) cooperative discipline, Raffini's (1996) student autonomy, Marshall's (1998) responsibility, Curwin and Mendler's (1988) and DiGuilio's (2000) student dignity, Campbell's (1999) and Burden's (2000) multifaceted student motivation, Charles' (2000) synergy, Churchward's (2003) honor system, and Kagan, Kyle, and Scott's (2003) win-win. Constructivist teaching has been embraced by a number of strategists, most notably Wood (1992), Kohn (1996), Hoover and Kindsvatter (1997), and Good and Brophy $(1996,2000)$.

Available now, more than ever before, are a variety of classroom management strategies designed to best the teacher's distinct personality and teaching style and provide solidarity for the principal. Moreover, it is necessary for teachers to undertake a front-line position of positive behavior expectations in their own classrooms, and administrators, likewise, are expected to assume not only a managerial role in the classroom but in the overall system at large. In schools where the teachers and administrators do not work collaboratively, the student, all too often, can easily dictate any single aspect of the school operation. To counteract this, educators must have an understanding of the root of behavioral problems, develop skills based on a shared vision, and develop appropriate measures to correct such distractions as they arise (Oliva, 1993).

\section{FORGING COLLEGIAL COMMITMENTS}

Successful management of the learning environment is a school-wide, collegial commitment aimed to reflect fairness and cooperation in a supportive, interactive atmosphere. Failure on the part of the administration to infuse the learning environment with such a collegial approach not only brings about teacher isolation, a major deterrent to bringing people on board in order to initiate meaningful and purposeful change (Hopfengardner and Leahy, 1987; Wagner, 2000), but it also serves as a key source of teacher stress (Kain, 1997). Harris (1999) conducted a study to determine if a cause-effect relationship existed between an administrator's leadership ability and teacher stress. His findings include an interesting result - schools that report the lowest teacher stress are also those schools in which the 
principals not only communicate a clear vision, but understand the importance of developing and maintaining strong working relationships with the faculty and staff.

Successful school leaders indicate that getting the culture right must precede any and all school improvement efforts (Sergiovanni, 2004). Ultimately, it is the administrator's responsibility to communicate high expectations for instruction to all teachers, who, in turn, evidence their expectations for all students through their practice. Heightened teacher expectation results in increased student achievement that is both highly valued and publicly recognized. "Research has indicated that in classes where teachers held higher expectations for all students, higher general student performance resulted" (Burke, et al., 2004, p. 311). A teacher's high expectations of students will likely diminish over time unless the students comprehend and value the worth of what they are learning. In an internalized reckoning of the varied opportunities for learning, students will often establish their own set of expectations. When a teacher exhibits enthusiasm and interest in the content, students' self-expectations are more apt to increase. "The way you present learning activities helps frame your students' expectations" (Zabel \& Zabel, 1996, p. 180).

Through introducing and remaining constant in the implementation of effective management strategies, principals and lead teachers provide the necessary foundation for teachers to develop or enhance a robust learning environment. Incompetent educators believe that "they can function more successfully individually than they can collectively" (Zmuda, Kuklis, \& Kline, 2004, p. 20). Principals who wish to overcome this attitude of reluctance might well choose to empower teachers, a concept that is inherent in productive leadership. In empowerment, administrators consciously decide to share decision-making opportunities with those who are most affected by the outcomes of the decisions. In fact, empowerment may often reach into areas beyond mere decision-making, including delegation of authority, site-based management, and teamwork (Hoy \& Miskel, 1996).

When teachers are empowered, their leadership skills grow. Bolin (1989) presents a framework on empowerment by calling for teachers to "participate in the determination of school goals and policies and the right to exercise professional judgment about the content of the curriculum and means of instruction" (p. 83). To do so requires an open, encouraging administrative leadership style, one where principals begin "viewing teachers as decision makers instead of 'paper pushers' who perform bureaucratically designated steps in educating children" (Blase \& Blase, 1994, p. 7).

Not to confuse the issue, but the research that directly links teacher empowerment to higher student achievement may not be all that decisive. Due, to a large extent, to the intricacy of making such a connection, the research here has found little to no correlation between empowerment and student productivity (Louis, Marks, \& Kruse, 1996; Marks \& Louis, 1997). "In short, the link between teacher empowerment and student achievement has been hard to establish in schools because the relationship is so complex" (Sweetland \& Hoy, 2000). On the other hand, schools who operate under shared values and positive learning environments have been shown to make a difference in student achievement, and, coincidence or not, those are the very schools that reflect teacher empowerment (Marks \& Louis, 1997).

For the most part, the managerial aspect of schools involves not only the notion of empowerment, but it encompasses a wide variety of activities that differ day-to-day, week-to-week, and month-to-month. Unfortunately, many activities become subjected to tedium, alterations of schedule, bell and intercom interruptions, curriculum mandates, and the like. When such is the case, they may appear fragmented (Yukl, 1994), and students' feelings about the learning activities "often generalize to the teacher who requires them" (Zabel \& Zabel, 1996, p. 179). Teachers, likewise, can grow weary of administration-perpetuated interruptions. If schedule changes that disrupt routine become too frequent or abrupt, changes in plans may be based more on personal moods and temperaments than on what is actually best for the students. The core of preventing illogical shifts is proactive planning. Whether teacher or principal, it is important to have several routes to learning planned ahead, as opposed to the "one-size-fits-all lesson" (Cooper, et al., 2003, p.169). Acting proactively allows for mental preparation; the focus becomes what the best approach might be and what the desired outcome really is. 


\section{ENHANCING MULTICULTURAL EDUCATION}

Proactive planning is never more apparent than with issues of diversity. In managing learning environments, diversity considerations are crucial factors. For purposes of developing inclusion strategies in an educational setting, the definition of diversity encompasses not only ethnic and racial, but socioeconomic status, gender, sexual orientation, exceptionality, religion, age, and English language proficiency as well (Manning \& Bucher, 2005; Gollnick \& Chinn, 2002). Are schools today institutions where all students can learn? The initial dilemma principals face is how educate "all -- not just some -- students to higher standards and how to prepare them for continuous learning. We don't know how to do this; we've never done it before" (Wager, Understanding the urgent need for change, II 7).

From a historical perspective, reckoning with diversity issues were once decisions made by ethical teachers who understood the importance of providing an educational climate in which all students felt accepted and respected. Frequently, good teachers would design special lessons or activities to accommodate students who had an exceptionality or were language deficient. Others, fewer still, would reckon with socio-economic status, age differences, ethnicity, race, and/or religion on occasion, but attention to sexual orientation was all but nonexistent. For many teachers, if both the students and the teacher in the classroom were predominately white, there was probably little effort to multiculturalize the instruction. "Disparate sociocultural systems would fade in favor of an allenveloping, superior one; socialization patterns for home and school would be monolithic" (Clayton, 2003, p. 131).

Multicultural education is not a new phenomenon; however, with the increase in immigration, the need becomes more evident. While multicultural education includes issues not related to immigration, indeed, immigration was, and is still, very much a part of the American scene. "The United States is thus not only a nation of immigrants as seen in some idealized and romanticized past; it is also a living nation of immigrants even today" (Nieto, 1992, p. $\mathrm{xxv}$ ). Educators' attention to diversity is even more pronounced today, as "the number of culturally diverse learners increases daily" (Baruth \& Manning, 1992, p. 2). Whites, long the predominate race in the United States, are projected to decline in percentage numbers by the year 2050 (Larson \& Ovanda, 2001). "By historical standards, the 33.1 million immigrants living in the United States is unprecedented. Even at the peak of the great wave of immigration in the early 20th century, the number of immigrants living in the United States was only 40 percent of what it is today (13.5 million in 1910)" (Camarota, 2002, p. 1). Unfortunately, schools have not fully capitalized upon opportunities to bring such rich awareness and appreciation into the classroom. "The pain and alienation of the immigrant experience, however, have rarely been confronted in our schools" (Nieto, 1992, p. xxv).

Today, however, the "dramatic diversification that is currently underway in the United States" (Diller \& Moule, 2005, p. 19) provides the impetus needed to teach toward multicultural competence. Not only do educators in the United States have the difficult task of discerning group members who share common dimensions of diversity, but they must also be aware that such dimensions are not uniform within the groups themselves. Indeed, defining diversity becomes a difficult task, even more so because "dimensions of diversity are in a constant state of flux" (Bucher, 2000, p. 16).

Such a teaching strategy is more of a mind-set than any particular activity the teacher pulls out of the file in order to celebrate a particular day of the year. "Multicultural education is seen as a process instead of a product" (Gay, 2004, p. 33). Understanding diversity, or, as Bucher purports, developing "diversity consciousness" skills will "open up your mind to opportunities in all realms of life" (Bucher, 2000, p. 96). Multicultural education is a way of thinking that infuses all content areas with adequate support for each student. Adequate support means that the school culture must include an understanding of and appreciation for the "life experiences of those who are culturally different" (Diller \& Moule, 2005, p. 3). Doing so requires proactive planning, and educators who do it best understand that the rewards for employing such an educational mind-set are often the result of hard work. "There is a general agreement among educators and counselors that cross-cultural work is more demanding, challenging, and energy draining..." (Diller \& Moule, 2005, p.173). It is because of the relationships of learning to the lives of the students that teachers find themselves puzzling over approaches that may be unique and often exciting. "Multicultural education needs to be placed within a framework of empowering attitudes and beliefs rather than viewed as just pedagogy or curriculum" (Nieto, 1999, p. 84). 
So, what is the principal's role in bringing on board a multicultural mind-set? Historically speaking, a principal, once considered a supervisor or manager of the school, has seen several shifts over time. When, on October 4, 1957, the Soviet Union launched its satellite Sputnik into orbit, the impact was profoundly felt on American schools. The role of the principal took on a whole new meaning. Many principals of small schools either had to make the switch to join a larger school system or lose their jobs all together because "Sputnik galvanized a movement to modernize and enlarge America's schools. The best and the brightest agreed that small schools burdened our ability to win the Cold War" (Mitchell, 2000, ๆ2). This set the stage for future changes, many with direct impact on the everincreasing demands of the principal. "The school effectiveness literature of the early 1980s, the classroom effectiveness literature, and the publication of A Nation At Risk, with its dire broadcast of the grim condition of American education, all synergized as a powerful and unrelenting spotlight focused on the principal" (Lockwood, 2004, II4).

The Elementary and Secondary Act of 1965, enacted by President Lyndon Johnson, put into effect funds for K-12 education, including money for professional development, parent programs, and instructional supplies. Since that time, the ESEA has been reauthorized by Congress every five years and has undergone several changes. Today, the ESEA, now known more widely as "No Child Left Behind," or NCLB, "establishes laudable goals - high standards, accountability for all, and the belief that all children can learn, regardless of their background or ability"

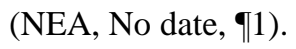

NCLB offers a new set of challenges to the principal. Now, principals need to understand standards, promote adequate yearly progress, and collect and comprehend data in order to determine where each student is academically in relation to the targeted goal and state standards. Now, principals need to "lead staff in analyzing state assessment data, develop monitoring plans to track student progress on the student achievement goals with classroom data, provide time and expectations that teams analyze monitoring data and examine student work on an ongoing basis, and identify key questions for the teams to address and end products that teams will produce" (Hillcrest \& Main, No date, What do principals need to know and do?, I1).

As a result, the principal moved from a managerial position to one of being primarily accountable for student achievement in the school. The active engagement of each child became a concern and multiculturalism in education became a key to unlock the learning for many of the school's youth. "A major goal of multicultural education is to improve academic achievement" (Banks \& McGee Banks, 1993, p. 4). The promotion and inclusion, therefore, of multicultural education in the school has become an inherent part of every principal's bailiwick.

\section{INCORPORATING TECHNOLOGY}

Proactive planning on the part of the principal is necessary in order to maximize the use of technology throughout the school. "Establishing clear expectations can help school leaders increase successful use of technology in schools" (Valdez, 2004, Technology leadership overview, 7). Several research studies have concluded that technology, when used appropriately, can be a significant factor in increasing student learning (Byrom \& Bingham, 2001; Clements \& Sarama, 2003; Mann, Shakeshaft, Becker, \& Kottkamp, 1999; Valdez, et al., 2000; Wenglinsky, 1998).

Using technology appropriately is the key. While opinions differ as to whether or not computer games have a place in education (Jackson, 2004), the ultimate purpose of using technology is a means to an end -- that of helping students learn. Teachers, according to Bailey, (2001) may incorporate technology into the classroom in any of three ways: as an aid to enhance learning, as subject for learning in and of itself, and as a means of empowering students. Regardless of the specific purpose, successfully integrating technology to the school's vision will result in higher student gain (Hawkins, Panush, \& Spielvogel, 1996).

Education leaders recognize that the proper use of technology not only aids in acquiring data for various assessments and in increasing the efficiency of teaching, but it also provides opportunities for students to work with information tools that will better prepare them for their futures. "Technology education has gone from being important for all students to absolutely essential ..." (Kane, 2002, p. 1). It is the responsibility of teachers and administrators to 
help students become adept in using technology. This charge is outlined in enGauge ${ }^{\circledR} 21$ st Century Skills: Literacy in the Digital Age (NCREL \& Metiri Group, 2003).

Utilizing technology to enhance student learning is certainly an important use of resources. However, principals would be remiss if they failed to use the same tools to gather pertinent data for the purpose of staying abreast of local, state, and national trends and for structuring plans to address areas targeted for improvement. "As school leaders begin to re-focus more exclusively on student learning, they frequently discover they must restructure the entire organization" (Carr, 2001, p. 36). School leaders who rely heavily upon data to form their visions are referred to as data-driven. The benefits of being a data-driven school are many, but they all depend upon a "major motivator and technical and financial support" (Noyce, Perda \& Traver, 2000, Promoting data driven cultures, 1).

Technology can also be used in the classroom of a creative teacher or in the school of a creative principal. But technology use cannot operate in a vacuum; the application of learning theory, the recognition of how students learn, the implementation of various models of teaching, and the differentiation of instruction to address students' needs are all underpinnings of any use of technology in the school. Operating on this foundation, the creative educator encourages problem-solving and continual learning in preparing students to live successful lives (Beyer, 2001). In an environment that promotes growth, effective instructional leaders strive to maintain open communications and develop cooperative, non-threatening partnerships with educators who "encourage openness, create a willingness to experiment, and provide freedom to make and admit mistakes in the interest of improvement" (Blase \& Blase, National leadership through the teacher's eyes, 3).

Technology is vital in providing the wherewithal for education leaders to communicate with each other, students, families, and patrons. Essential to the role of principals in the Information Age is the process of sending and receiving data with people who can best assist in the development of the student. As we look forward to examining the need for collaboration, it is important to keep in mind that technology use is key to such communication.

"Technology is rapidly reducing the communications barrier imposed by distance to a state of near irrelevance. Today, physical barriers matter far less than the logical barriers that separate sources and users of data"

(Penzias, 2003, chap. 7, II 1).

\section{COLLABORATION WITH FAMILIES AND COMMUNITY MEMBERS}

Principals also provide leadership through collaboration by establishing the tone whereby parents, families, and community members are encouraged to be involved in their children's education.

Parents who are active partners in their children's education are more apt to become and remain strong supporters of the school. Principals looking to improve schools should not overlook the importance of the involvement of parents and families. A variety of studies (Henderson \& Berla, 1994) indicate that heightened involvement of parents results in positive impacts on students' attitude, attendance, and academic achievement. The Internet website for the Center for Public Policy Priorities focusing on a Texas program entitled "Measuring Up" (1999) states it clearly, "parents can increase children's academic success through involvement with schools and communities. Parental involvement improves student morale, attitudes, and academic achievement across all subject areas." (Parent involvement in education, 1). The American Association of School Administrators agrees, "The research about parent involvement is clear. When parents are involved in their children's education, children excel" (Leader's Edge, Spring, 1998, ๆ 1).

Parents have an important role to play not only in encouraging their children to succeed academically, but in becoming active and contributing members to the school society as well. By doing so, social development and positive behavior expectations are reinforced at home and provide fodder for the discussion of shared goals through frequent conversations between parents and teachers. If positive interactions occur, the chance of success increases (Chang, 1994). Not only are higher grades and better attendance a result of family involvement, but other success factors come into play as well, including displays of positive attitudes, higher graduation rates, and greater enrollment in higher 
education (Strong families, strong schools, 1994).

Positive community and family interactions foster an environment that enables students to be successful. In reverse, students who live without positive reinforcement often create negative attitudes, lash out at people who achieve success, become schoolyard bullies, become apathetic toward school, withdraw inward as a means of protecting themselves, or behave in ways that attract attention, even if it is negative. In the case of the latter, students "prefer the pain of humiliation or other forms of punishment to receiving no attention. If they fail to receive the attention they desire, they do things that cannot be ignored" (Edwards, 2004, p. 97).

In an effort to capitalize on the positive aspects of school, principals have, for many years, sought ways to involve parents and to celebrate students' successes. To maximize opportunities for involvement, the school leaders need to turn an eye inward. Any plan to involve families in their children's education needs to examine reasons why involvement is an issue. Is the school environment accepting and welcoming? Are teachers adequately trained in communicating with families and in expressing appreciation for their involvement? What barriers exist to prevent or dissuade families from being important participants? On the positive side, it should be noted that parent-teacher organizations have evolved, Parents as Partners groups have become an important voice, parent-teacher conferences have more emphasis, parent-led after-school programs have grown significantly, community partnerships have emerged, and more volunteer opportunities that bring families and school personnel together have arisen (Manning \& Bucher, 2005).

Reaching out to parents is not the only way principals can demonstrate leadership and promote success. Schools that are positively regarded in the community are those in which the principal organizes opportunities for the sole purpose of actively seeking out partnerships with community members, businesses, and other governmental agencies. Schools are a reflection of the community at large; if the schools have a diverse population, then so does the community. Seeking ways to reach out to the community and demonstrate the importance of providing cultural competence may be one of the best learning opportunities the school can provide the community. American school systems perform within communities that include a wide variety of ages, education levels, and lifestyles (Powell, 2005).

When principals keep their communities well informed on the mission, goals, and achievements, the communities are more positively involved (Weller, 2004). Communication between teachers and parents, as well as between principals, parents and patrons, is served best when the line is two-directional and frequently used. Schools with positive and strong internal and external communication networks find that change and cooperation are instituted in a much smoother manner. Educators must develop these professional networks and capabilities in order to respond to the challenges of the system (Synder, Acker-Hocevar, \& Synder, 2000).

"Good communication is difficult" (Chang, 1994, p. 13). Teaching future educators and administrators that vital to their success as professionals are communication skills and strategies, an understanding of the importance of a solid public relations program, the knowledge of how to nurture such a program, and the ability to foster support from faculty, staff, students, parents, and patrons. The benefits of approaching learning through collaboration affords future educational leaders the advantages of learning from each other, of depending on each other, and of engaging in realworld educational opportunities (Bruffee, 1999). All of these focus on the importance of communication. The principal must take a vigorous role in providing the needed leadership in the community by using a variety of key communication skills (Weller, 2004).

"Seek first to understand, then to be understood," recommends Covey (1990, p. 235). In collaborating with any group, whether teachers, students, families, or community members, the prudent education leader schooled in interpersonal communication understands that listening is key to advancing change and problem-solving. "Listening is a key component of quality management. Most understand that better decisions are made when education leaders listen to staff, parents, and the community" (Jenkins, 1997, p. 131). Schilling (2000) cautions that it is not enough to listen, but, rather, the education leader must not only choose to want to listen but develop skills that visibly express that attitude. From listening come a variety of other effective communication skills, including questioning, giving feedback, paraphrasing, perception checking, describing behavior, as well as a host of specific non-verbal behaviors 
(Irmsher, 1996).

Understanding that communities can enhance our efforts as a school should increase the motivation to learn and understand communication efforts. Principals and teachers alike need to understand that we cannot expect kids to lead the way without fervent leadership from the adults (Powell, 2005). Teachers and administrators are with the children a majority of the day, and on average, education leaders are "engaged in one form or another of communication for about 70 percent of their waking moments" (Irmsher, 1996, \ 1). Through establishing a strong communication network with families and patrons, education leaders are better equipped to provide safe, caring, nurturing, challenging, and engaging academic environments for all children.

\section{SUMMARY}

Providing leadership in today's schools is not an easy task. Change, inherent in learning, provides a fluid foothold at best. The education leader today focuses on instruction, culture, management, strategies, and community, with many areas demanding immediate attention. Because student progress is, always has been, and will continue to be in the future, the reason schools exist, educators must demonstrate leadership that promotes the successes of all students by managing the learning environment and by collaborating with families and community members. With a shared vision to guide, various cultures to embrace, technology to explore, and data to assess, leaders of effective schools recognize the value of and promote positive educational environments that are framed with a healthy variety of research-based educational practices. Without a strong collegial commitment for improvement that operates on affording effective teachers the latitude to be innovative and creative, and without an effective communication system designed to pull in the families and patrons, the work of education leaders trying to promote student success will only be met with disappointment, frustration, and, ultimately, failure.

Good leaders create a vision, articulate the vision, passionately own the vision, and relentlessly drive it to completion.

(Thomas Hardy)

\section{REFERENCES}

1. Albert, L. (1996). Cooperative discipline. Circle Pines, MN: American Guidance Service.

2. American Association of School Administrators. (1998, Spring). Promoting parent involvement. Leader's Edge, 2. Retrieved February 9, 2005, from http://www.aasa.org/publications/leaders_edge_spring98.htm

3. Bailey, G. D. (2001). Technology leadership: Ten essential buttons for understanding technology integration in the $21^{\text {st }}$ century. Manhattan, KS: Kansas State University, College of Education.

4. Banks, J.A. (1993). Multicultural education: Characteristics and goals. Multicultural education: Issues and perspectives, 2, 3-28.

5. $\quad$ Banks, J.A. \& McGee Banks, C.A. (Ed.). (1993). Multicultural education: Issues and perspectives ( $2^{\text {nd }}$ ed.). Needham Heights, MA: Allyn and Bacon.

6. Baruth, L.G. \& Manning, M. L. (1992). Multicultural education of children and adolescents. Needham Heights, MA: Allyn and Bacon.

7. Beyer, B.K. (2001). Developing minds: A resource book for teaching thinking ( ${ }^{\text {rd }}$ ed.). Alexandria, VA: Association for Supervision and Curriculum.

8. Black, S. (2001, January). Morale matters. American School Board Journal. Retrieved February 12, 2005, from http://www.asbj.com/2001/01/0101research.html

9. Blase, J. \& Blase, J. (No date). National leadership through the teacher's eyes: What principal behaviors do teachers think best promote teaching and learning in schools? Retrieved October 12, 2004, from the World Wide Web http://www.lisbon.k12.nh.us/Specials/nationalleader.htm

10. Blase, J. \& Blase, J. R. (1994). Empowering teachers: What successful principals do. Thousand Oaks, CA: CorwinPress.

11. Bolin, F. (1989). Empowering leadership. Teachers College Record, 91(1), 81-96.

12. Bruffee, K.A. (1999). Collaborative learning: Higher education, interdependence, and the authority of knowledge. Baltimore: The Johns Hopkins University Press. 
13. Bucher, R. (2000). Diversity consciousness: Opening our minds to people, culture, and opportunities. Upper Saddle River, NJ: Prentice Hall.

14. Burden, P. (2000). Powerful classroom management strategies: Motivating students to learn. Thousand Oaks, CA: Corwin Press.

15. Burke, W., Gardner, T., Moody, C. D., Pasch, M., Sparks-Langer, G. M., \& Starko, A. J. (2004). Teaching as decision making: Successful practices for the secondary teacher $\left(2^{\text {nd }}\right.$ ed.). Upper Saddle River, NJ: Pearson Merrill Prentice Hall.

16. Byrom, E. \& Bingham, M. (2001). Factors influencing the effective use of technology for teaching and learning: Lessons learned from the SEIR/TEC intensive site schools. Southeast Initiatives Regional Technology in Education Consortium. Retrieved June 25, 2004, from http://www.seirtec.org/publications/ lessons.pdf

17. Camarota, S.A. (2002, November). Immigrants in the United States - 2002: A snapshot of American's foreign-born population. Backgrounder. Retrieved May 5, 2004, from http://www.cis.org/articles/2002/ back1302.html

18. Campbell, J. (1999). Student discipline and classroom management: Preventing and managing discipline in the classroom. Springfield, IL: C.C. Thompson Publisher.

19. Canter, L. (1976). Assertive discipline: A take charge approach for today's educator. Seal Beach, CA: Canter and Associates.

20. Carr, N. (2001). Making data count. American School Board Journal, 188(11), 34-37.

21. Center for Public Policy Priorities. (1999). Measuring up the state of Texas education: Parental involvement in education. State of Texas Children: 2000 Factbook. Retrieved February 7, 2005 from http://www.cppp.org/ kidscount/education/parental_involvement.html

22. Chang, R.Y. (1994). Success through teamwork. San Francisco: Jossey-Bass Pfeiffer.

23. Charles, C. (2000). The synergetic classroom. Boston: Allyn and Bacon.

24. Churchward, B. (2003). Discipline by design: The honor level system. Retrieved January 5, 2005, from www.honorlevel.com.

25. Clayton, J. (2003). One classroom, many worlds: Teaching and learning in the cross-cultural classroom. Portsmouth, NH: Heinemann.

26. Clements, D.H. \& Sarama, J. (2003). Strip mining for gold: Research and policy in educational technology A response to fool's gold. Educational Technology Review, 11(1), 7-69. Retrieved June 25, 2004, from http://www.aace.org/pubs/etr/issue4/clements2.pdf

27. Coloroso, B. (1994). Kids are worth it! Giving your child the inner discipline. New York: Avon Books.

28. Connors, N.A. (2000). If you don't feed the teachers, they eat the students: A guide to success for administrators and teachers. Nashville, TN: Incentive Publishers.

29. Cooper, J (Ed.). (2003). Classroom teaching skills ( $7^{\text {th }}$ ed.). Boston: Houghton Mifflin Company.

30. Covey, S. (1990). The seven habits of highly effective people. New York: Fireside Books.

31. Curwin, R. \& Mendler, A. (1988). Discipline with dignity. Alexandria, VA: Association for Supervision and Curriculum Development.

32. Danielson, C. (1996). Enhancing professional practice: A framework for teaching. Alexandria: Association for Supervision and Curriculum.

33. Deal, T. \& Peterson, K. (1993). Strategies for building school cultures: Principals as symbolic leaders. Educational leadership and school culture, 89-99.

34. DiGiulio, R. (2000). Positive classroom management ( $2^{\text {nd }}$ ed.). Thousand Oaks, CA: Corwin Press.

35. Diller, J. \& Moule, J. (2005). Cultural confidence: A primer for educators. Belmont, CA: Thomson Wadsworth.

36. Eaker, R., DuFour, R. \& DuFour, R. (2002). Getting started: Reculturing schools to become professional learning communities. Bloomington, IN: National Educational Service.

37. Edwards, C. (2004). Classroom discipline and management (4 ${ }^{\text {th }}$ ed.). New York: John Wiley \& Sons, Inc., 96-97.

38. Emmer, E. \& Aussiker, A. (1989). School and classroom discipline programs: How do they work? In O. Moles (Ed.). Strategies to reduce student misbehavior. Washington DC: U.S. Department of Education, Office of Educational Research and Improvement.

39. Fay, J. \& Funk, D. Teaching with love and logic. Golden, CO: Love and Logic Press. 
40. Gay, G. (2004). Curriculum theory and multicultural education. In J. Banks \& C. A. McGee Banks (Ed.). Handbook of Research on multicultural education ( $2^{\text {nd }}$ ed.).

41. Glasser, W. (1990). The quality school: Managing students without coercion. New York: Harper \& Row.

42. Glasser, W. (1998). Choice theory in the classroom. New York: Harper Collins.

43. Gollnick, D. M. \& Chinn P. C. (2002). Multicultural education in a pluralistic society (6 ${ }^{\text {th }}$ ed.). Upper Saddle River, NJ: Merrill Prentice Hall.

44. Good, T. \& Brophy, J. (1996). Teaching effects and teacher evaluation. Handbook of Research on Teacher Education (2 $2^{\text {nd }}$ ed.). New York: Macmillan.

45. Good, T. \& Brophy, J. (2000). Looking in classrooms ( $8^{\text {th }}$ ed.). New York: Addison Wesley Longman.

46. Harris, C.A. (1999). The relationship between principal leadership styles and teacher stress in low socioeconomic urban elementary schools. Dissertation Abstracts International. Retrieved June 18, 2004, from http://www.asbj.com/2003/10/1003research.html

47. Hawkins, J., Panush, E.M., \& Spielvogel, R. (1996, December). National study tour of district technology integration . (Summary report). New York: Center for Children and Technology Education Center.

48. Henderson, A. \& Berla, N. (1994). A new generation of evidence: The family is critical to student achievement. Washington D.C.: National Committee for Citizens in Education, Center for Law and Education.

49. Hillcrest and Main, Inc. (No date). What do principals need to know and do? Retrieved February 9, 2005 from http://www.meetayp.com/schools/principals.html\#2

50. Hoover, R. \& Kindsvatter, R. (1997). Democratic discipline: Foundation and practice. Upper Saddle River, NJ: Merrill.

51. Hopfengardner, J.D. \& Leahy, P. E. (1987, November). Beyond induction: A collegial support system for experienced teachers. Paper presented at the National Staff Development Council Conference, Seattle, WA.

52. Hoy, W. \& Miskel, C. (1996). Educational administration: Theory, research, and practice (5 ${ }^{\text {th }}$ ed.). New York: McGraw-Hill.

53. Irmsher, K. (1996). Communication skills. Retrieved October 18, 2004, from the World Wide Web http://eric.uoregon.edu/publications/digests/digest102.html

54. Jackson, L. (2004). Tech-ing wisely in k-2 classrooms. Education World. Retrieved July 25, 2004 from http://www.educationworld.com/a_tech/tech/tech195.shtml

55. Jenkins, L. (1997). Improving student learning: Applying Deming's quality principles in classrooms. Milwaukee, WI: Quality Press Books.

56. Jones, F. (1987). Positive classroom discipline. New York: McGraw-Hill.

57. Kagan, S., Kyle, P. \& Scott, S. (2003). Win-win discipline course workbook. San Clement, CA: Kagan Publishing.

58. Kain, D. L. (1997). Critical incidents in teacher collaboration on interdisciplinary teams. Research in Middle Level Education Quarterly, 21(1), 1-29.

59. Kellough, R.D. \& Kellough N. G. (2003). Secondary school teaching: A guide to methods and resources. Upper Saddle River, NJ: Merrill Prentice Hall.

60. Kane, G.C. (2002). Importance of technology education. State Consultant for Technology Education Newsletter. Retrieved October 29, 2004, from http://www.careereducationportals.com/directory/educationimportance-in-technology.thml

61. Kohn, A. (1996). Beyond discipline: From compliance to community. Alexandria VA: Association for Supervision and Curriculum Development.

62. Kounin, J. (1970). Discipline and group management in classrooms. New York: Holt, Rinehart and Winston.

63. Larson, C. \& Ovando, C. (2001). The color of bureaucracy: The politics of equity in multicultural school communities. Belmont, CA: Wadsworth/Thompson Learning.

64. Lockwood, A.T. (1996). The changing role of principals: An interview with Philip Hallinger. North Central Regional Education Laboratory. Retrieved February 12, 2005, from http://www.ncrel.org/cscd/ pubs/lead31/31hallin.htm

65. Louis, K., Marks, H., \& Kruse, S. (1996) Teachers' professional community in restructuring schools. American Journal of Education, 33, 757-798.

66. Mann, D., Shakeshaft, C., \& Kottkamp, R. (1999). West Virginia story: Achievement gains from a statewide comprehensive instructional technology program. Milken Family Foundation. Retrieved June 25, 2004, from 
http://www.mff.org/publications/publicaions.taf?page $=155$

67. Manning, M.L. \& Bucher, K.T. (2005). Teaching middle school. Upper Saddle River, NJ: Pearson Merrill Prentice Hall.

68. Mathews, D. (1996). Is there a public for public schools? Dayton, OH: Kettering Foundation Press.

69. Marks, H. \& Louis, K. (1997). Does teacher empowerment affect the classroom? The implications of teacher empowerment for instructional practice and student academic performance. Educational Evaluation and Policy Analysis, 19, 245-275.

70. Marshall, M. (1998). Fostering social responsibility. Bloomington: Phi Delta Kappa Educational Foundation.

71. Mitchell, S. (2000, summer). Jack and the giant school. The Journal of the New Rules Project, 2. Retrieved February 12, 2005, from http://www.newrules.org/journal/nrsum00schools.htm

72. National Education Association. (No date). Urge Congress: Fix and Fund 'No Child Left Behind'. Retrieved February 11, 2005, from http://www.nea.org/lac/esea/index.html

73. Nieto, S. (1992). Affirming diversity: The sociopolitical context of multicultural education. White Plains, NY: Longman Publishing Group.

74. Nieto, S. (1999). The light in their eyes: Creating multicultural learning communities. New York: Teachers College Press.

75. North Central Regional Educational Laboratory \& Metiri Group (2003). enGauge $21^{\text {st }}$ century skills: Literacy in the digital age. Retrieved June 25, 2004, from North Central Regional Educational Laboratory from http://www.ncrel.org/engauge/skills/skills.htm

76. Noyce, P., Perda, D., \& Traver, R. (2000). Creating data-driven schools. Educational leadership, 52(5), 5256. Retrieved October 19, 2004, from the Association for Supervision and Curriculum Development FullText database.

77. Oliva, P.F. (1993). Supervision for today's schools (4 ${ }^{\text {th }}$ ed.). White Plains, NY: Longman Publishing Company.

78. Pejza, J.P. (1985, April). The catholic school principal: A different kind of leader. Paper presented at the Annual Meeting of the National Catholic Educational Association, Saint Louis, MO.

79. Penzias, A. (2003). Education for an information age. Teaching in computerized classroom. Retrieved October 7, 2004, from World Wide Web http://pitt.edu/ edindex/Info-Age4index.html

80. Phillips, G. \& Wagner, C. (2003). School culture assessment. Vancouver, British Columbia: Agent 5 Design.

81. Powell, S.D. (2005). Introduction to middle school. Columbus, OH: Merrill Prentice Hall.

82. Raffini, J. (1996). 150 ways to increase intrinsic motivation in the classroom. Boston: Allyn \& Bacon.

83. Robbins, P. \& Alvy, H. (1995). The principal's companion. Thousand Oaks, CA: Corwin Press.

84. Schilling, D. (2000). Be an effective listener! Women's Media.Com: The Self-Improvement Site for Women. Retrieved February 9, 2005, from http://www.womensmedia.com/seminar-listening.html

85. Seeley, D.S. (1992, April). Visionary leaders for reforming public schools. Paper presented at the Annual Meeting of the American Educational Research Association, San Francisco, CA.

86. Sergiovanni, T. (2004, May). Building a community of hope. Educational Leadership, 61, 33-37.

87. Stephen, S. (1994). Leadership for school culture. Clearinghouse on educational policy and management. Retrieved July 14, 2004, from http://www.eric.uoregon.edu/publications/digests/digest091.html

88. Sweetland, S. \& Hoy, W. (2000, December). School characteristics and educational outcomes: Toward an organizational model of student achievement in middle schools. Educational Administration Quarterly 36(5), 703-729.

89. Synder, K.J., Acker-Hocevar, M., \& Synder, K.M. (2000). Living on the edge of chaos: Leading schools into the global age. Milwaukee, WI: Quality Press.

90. Tinzmann, M. B., Jones, B. F., Fennimore, T. F., Baker, J., Fine, C., \& Pierce, J. (1990). What is the collaborative classroom? Oak Brook, IL: NCREL.

91. U.S. Department of Education (1994). Strong families, strong schools. Retrieved October 31, 2004, from http://www.uen.org/seop/html/parent/strong.html\#

92. Valdez, G. (2004, July). Technology leadership: Enhancing positivist change. Pathways to School Improvement. Retrieved October 2, 2004, from http://www.ncrel.org/sdrs/areas/issues/educatrs/ leadrshp/le700.htm

93. Valdez, G., McNabb, M., Foertsch, M., Anderson, M., Hawkes, M., \& Raack, L. (2000). Computer-based technology and learning: Evolving uses and expectations. North Central Regional Education Laboratory. 
Retrieved June 25, 2004, from http://www.ncrel.org/tplan/cbtl/toc.htm

94. Wagner, C. (2000, October). School culture analysis. Presented at the meeting of the Manitoba Association of Resource Teacher, Winnipeg, Manitoba.

95. Wager, T. (2001). Leadership for learning: An action theory of school change. Retrieved November 6, 2004, from http://www.pdkintl.org/kappan/k0101wag.htm

96. Weinstein, C.S. (2003). Secondary classroom management: Lessons for research and practice ( $2^{\text {nd }}$ ed.). Boston: McGraw-Hill.

97. Weller, D.L. (2004). Quality middle school leadership. Lanham, MD: Scarecrow Education.

98. Wenglinsky, H. (1998). Does it compute? The relationship between educational technology and student achievement in mathematics. Princeton, NJ: Educational Testing Service. Retrieved June 25, 2004, from $\mathrm{ftp} / / / \mathrm{ftp}$. ets.org/pub/res/technolog.pdf

99. Wood, G. (1992). Schools that work: America's most innovative public education programs. New York: Plume.

100. Wren, D.J. (1993). A comparison of the theories of adolescent moral development of Lawrence Kohlberg and Carol Gilligan: Alternative views of the hidden curriculum. Dissertation Abstracts International, 54 (04). (UMI No. 9325972)

101. Yukl, G. (1994). Leadership in organizations ( ${ }^{\text {rd }}$ ed.). Englewood Cliffs, NJ: Prentice Hall.

102. Zabel, R. H. \& Zabel, M. K. (1996). Classroom management in context: orchestrating positive learning environments. Boston: Houghton Mifflin Company.

103. Zmuda, A., Kuklis, R., \& Kline, E. (2004). Transforming schools: Creating a culture of continuous improvement. Alexandria, VA: Association for Supervision and Curriculum Development. 